\title{
Informe do BJIHS sobre o novo Qualis CAPES 2017-2020.
}

\author{
Éber Coelho Paraguassu (1)
}

\section{EDITORIAL}

Informamos aos nossos leitores e pesquisadores que o BJIHS estará na avaliação de periódicos a receber um Qualis que abrange o período de 2017-2020. Segundo os levantamentos internos dos envios de produção para a CAPES, o BJIHS poderá ser classificado na área mãe de Odontologia ou Interdisciplinar. Caso seja classificado na área de Odontologia, a expectativa de Qualis é B4 ou B3 e caso seja classificado na área Interdisciplinar, a expectativa de Qualis é B2 ou B1.

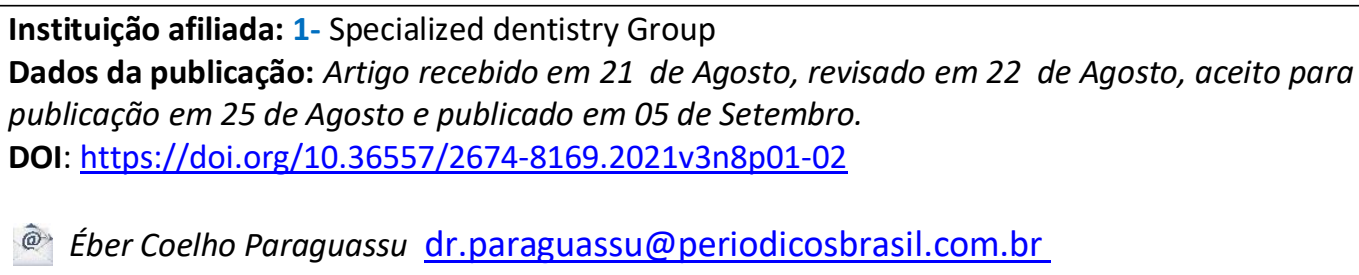

This work is licensed under a Creative Commons Attribution 4.0 International

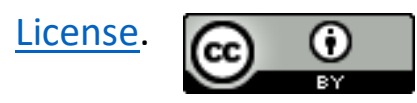

\section{REFERÊNCIAS}

Este artigo não possui referências. 